\title{
«ЖИВОЕ СЛОВО», Isegoria and the politics of deliberation in revolutionary Russia ${ }^{1}$
}

\author{
C.Brandist ${ }^{2}$
}

\begin{abstract}
This article aims to reflect on the notion of 'living word' from an historical trajectory, recognizing that although this subject has been very current among many intellectuals in the 'east' and the 'west 'it is still object of multiple questions which refer to different readings about this notion.

Keywords: Living-word; Soviet Context; Isegoria; Democracy.

Resumo: Este estudo tem como objetivo refletir sobre a noção de 'palavra viva'a partir de um percurso histórico, reconhecendo que embora o tema seja bastante atual entre uma maioria de intelectuais do 'Leste' e do 'Oeste', ainda tem sido objeto de uma série de inquietações que remetem para leituras distintas em torno da noção.
\end{abstract}

Palavras-chave: Palavra viva; Contexto Soviético; Isegoria; Democracia.

Exactly why the notion of живое слово became such a live issue among such a wide range of intellectual circles from a variety of intellectual backgrounds is a question that has not been given adequate attention in critical literature. This contribution attempts to address this question, pointing out that the term became a syncretic category in which a range of related but far from identical concerns coalesced but never resulted in a systematic synthesis. As such the current article is an exercise in what maybe called semantic palaeontology, revealing the various deposits of meaning, but nevertheless acknowledging that for different intellectual groups the ordering of the layers varied significantly.

\section{Democracy}

Discussions about the democratic order that should replace Tsarist autocracy was a sphere in which the notion of живое слово played an important role. The liberals who envisaged the establishment of a formal bourgeois democracy inevitably championed basic rights of assembly and 'freedom of speech' but elections were to be limited to realm of abstract citizenship, and control of the economic bases of power was to be excluded from any democracy. The reality of this is quite clear to see today in Greece, where elected governments have been instructed by unelected banks to impose austerity regardless of the popular will of the electorates. Bourgeois democracy also institutionalizes distance

1 This paper was elaborated according to goals and concessions of the President of Russian Federation as a support for the main scientific schools of the Federation, Project n. NSH.1140.2012.6.

G67 Living word. Logos- Voice- Mouvement - Gest. This article was published in a Russian edition with other authors under the supervision of V.V. Feshchenko. The authors' articles are researchers on linving word: linguists, poets, interpreters and collectors of oral poetry, specialists on reading and interpretative movements, professionals of theater, psichologists, musicians and researchers on the History of sciences.

2 Professor and researcher at Sheffield University -UK. Coordinator of Bakhtin Centre. 


\section{Conexão Letras}

between representatives and their electors and does not allow the latter to recall the former. Theorists of bourgeois democracy, such as the architects of the US constitution generally counterposed the formal democracy of the new system to that of ancient Athens, which was characterized by such notions as the 'tyranny of the democracy'.

Alternative conceptions of democracy among the more radical elements of the liberation movement inevitably referred back to the earlier notion of dëmokratia, which Aristotle defined as 'a constitution in which 'the free-born and poor control the government - being at the same time a majority' as opposed to an oligarchy, in which "the rich and better-born control the government- being at the same time a minority. Instead of an abstract 'freedom of speech', in which there is no guarantee one's perspective will be listened to, the more substation notion of Isegoria - the equality of speech operated in Athenian dëmokratia - the right to have one's say. Clearly dëmokratia had a social content in the Aristotelian definition. The dèmos had the sense of the poor masses (the Latin plebs), while kratos denoted a forcible grip on the disempowered wealthy few. As Paul Cartledge (1996: 183) notes, Dëmokratia was probably construed by its opponents negatively to mean something approaching the "dictatorship of the proletariat". Isegoria, the right to speak at the assembly was related to deliberative rhetoric (sym- bouleutikon), which involved Ethos (establishing confidence in the speaker); Pathos (arousing the feelings of the audience); Pistis (proof) given through Paradeigma (example), chosen according to its appropriateness, Prepon, which required the assessment of the specific sociological characteristics of an audience and an orientation on its values. The free assembly would listen to the cases presented speakers cases and vote (For discussions see Vickers, 1988; Ginzburg, 1999).

The dialectic of agitation and propaganda, which was developed by Plekhanov (Плеханов, 1892), and further developed by Arkadi Kremer and Julius Martov (Кремер, Мартов, 1896) was a theory of how revolutionaries can intervene 'free assemblies' like campaign meetings, trade unions and so on, by tailoring argumentation and evidence to the characteristics of the audience, see also Cliff, 1975: 42-68, 79-98. In Что делать? (Ленин, 1902) we see Lenin defining agitation in precisely this way, but specifically linking it to the notion of «Живое слово»:

«Пропагандист ... должен дать “много идей”, настолько много, что сразу все эти идеи, во всей их совокупности, будут усваиваться лишь немногими (сравнительно) лицами. Агитатор же, говоря о том же вопросе, возьмет самый известный всем его слушателям и самый выдающийся пример, - ...пре-

Раздел 1. История «живого слова»: люди, институты, теории

доставляя полное объяснение этого противоречия пропагандисту. Пропагандист действует поэтому главным образом печатным, агитатор — живым словом».

In the 1911 article «О старых, но вечно новых истинах», Lenin links the level of democracy in a given bourgeois society to the hegemony of the demos in the Athenian sense:

«Каждая капиталистическая страна переживает эпоху буржуазных революций, когда складывается та или иная степень демократизма, тот или иной уклад конституционализма или парламентаризма, та или иная степень самостоятельности, независимости, свободолюбия и инициативности “низов” вообще, пролетариата в частности, та или иная традиция во всей государственной и общественной жизни. 
Какова будет эта степень демократизма и эта традиция, - зависит именно от того, будет ли гегемония в решающие моменты принадлежать буржуазии или ее антиподу, будет ли первая или последний (опять-таки в эти решающие моменты) “центром притяжения для демократического крестьянства” и для всех вообще демократических промежуточных групп и слоев» (Ленин, 1973: 283)

Democracy here has a class character, that is, it involves a relation to economic relationships. Only the pressure of direct producers could prevent compromises between the bourgeoisie and the autocracy. Later (1919) he began to argue that without democratic control of economic resources any democracy would be effectively neutralized.

\section{Language and labour}

One particularly influential formulation in Russia at the time was that of the German monist philosopher, and follower of Schopenhauer Ludwig Noiré (1829-89). For him language and reason constitute a 'monon, captured in the notion of \ôyoç (Logos). Following Schopenhauer Noiré grounded language and reason in the Will (Noiré 1885; see also Hуарэ 1926). However, unlike Schopenhauer, Noiré stressed the practical aspects of Will and so argued that the roots of language arise in collective labour activity though the metaphorical transfer of sounds to the products of mans labour and to his perceptions. All language thus bears evidence of the sedimentations of labour activity. This metaphysics of labour was quickly reinterpreted in Marxist terms by Plekhanov and especially by Aleksandr Bogdanov and in subsequent interpretations the non-Marxist provenance of the idea was largely forgotten. Bogdanov developed Noiré's idea to argue that «связь элементов опыта в познании своей основою имеет соотношения элементов общественной активности в трудовом процессе» (Богданов, 1923: 293). For Bogdanov, different experiences give rise to different logics, worldviews, forms of culture and indeed science. Although this was fundamentally different from Leninist conception, in the USSR this idea became dominant, especially through the mediation of Bogdanovs erstwhile colleagues A.V. Lu- nacharskii and N.I. Bukharin. Indeed, it can be argued that what became known as 'Marxism-Leninism' was a product of Bukharins attempts to recast certain of Lenin's ideas according to a Bogdano- vite philosophy (see, for instance, Biggart, 1992). In his influential textbook Теория исторического материализма (Бухарин, 1922) Bukharin was to designate language part of the 'superstructure' on an economic base, which was completely absent from Marx's ideas and which, along with Noiré's ideas about the origin of language, became key elements of Nikolai Marr's theory of language. Bogdanov (Богданов, 1910: 5) argued the proletariat was struggling for «Всеобщая культурная гегемония» and this fed into the notion of cultural revolution that was to become the dominant conception at the end of the 1920 s.

\section{The Theurgic and Aesthetic}

Another quite distinct trend in the reception of the ideas of живое слово and Logos was connected with the heritage of orthodox theology in Russian philosophical thought and the way in which this affected the development of aesthetics in the years before 
the Revolution. Especially prominent in this regard is, of course, the symbolist poet V.I. Ivanov (Иванов, 1974), who viewed language and art as arising from the communal experience of ancient theatre, that is the Dionysian rites as described by Nietzsche. Ivanov identified the birth of the Logos with the ecclesiastical notion of слово. Now art has a theurgic nature, and the poetic word restructures subject from within, by participating in the establish-ment of Соборность. Interestingly this mystical notion was but a specific rendering of what Terry Eagleton (1990: 42-43) has called the 'the aesthetic ideal': Раздел 1. История «живого слова»: люди, институты, теории 'the aesthetic... is shorthand for a whole project of hegemony, the massive introjection of abstract reason by the life of the senses. What matters is not in the first place art, but this process of refashioning the human subject from the inside, informing its subtlest affections and bodily responses with this law which is not a law'.

This aesthetic ideal is one of individuals woven together into a unity with no detriment to their particularity.

Another Silver Age thinker, the classicist and ideologist of the so called 'Third Renaissance' F.F. Zelinskii was developing a very similar, but marginally less mystical conception. Both Ivanov and Zelinskii were to attune their ideas to the immediate post-Revolutionary situation. In 1922 Zelinskii argued that «слово, лежащее в основе и гражданской жизни взрослого человека и воспитания молодежи, было настоящим властелином древнего мира» (Зелинский, 1922: 171). This led to the identification of the living word with reason and the Greek term Logos (like the Russian слово) expressed both concepts. The growth of the conviction that Logos rules the world led to the mystical and evangelical understanding of the role of Logos, which was the «апофеоз» of the rule of the living word. This was inherited by Christianity and institutionalised by the deadening bureaucratic hand of the church for which the written Logos of the gospels should rule the world and mens hearts. Thus, «слово убило жест. Письмо убило слово» (Зелинский, 1922:172). With the rise of political activism, parliamentary speeches and courtroom appearances, especially following 1905, the idea that what was taking place in Russia was a veritable rebirth of the living word, живое слово, was widespread and a number of studies of the phenomenon arose (Зелинский, 1922: 172, see also Иванова, 2003).

\section{Syncretism}

The resonance of the idea of живое слово in the immediate post-revolutionary period is largely to be explained by the fact that these three trends were brought together into a syncretic (rather than synthetic) unity. This was particularly facilitated by the eclectic Commissar of Enlightenment Anatolii Lunacharskii in whose work, speeches and in the research programmes he framed, the three trends were brought together. While Lenin, Trotskii and others were preoccupied by the Civil War, Lunacharskii, an associate of Petrograd symbolists and long time colleague of Bogdanov, was guiding cultural policy. His attempt to fuse Leninist and Bogdanovite can be seen in his contribution to early Proletkul't documents, which as Mariia Levchenko correctly observes, constitute a palimpsest of Leninist and Bogdanovite terms. Lunacharskii argues at one point: «Целью культурно-просветительного движения пролетариата является вооружить рабочий класс знаниями, организовать его чувство искусством» (quoted in Левченко, 2007: $38-40)$. Here we can see the combination quite clearly. 
Several leading symbolists, including Ivanov, Aleksandr Blok and Andrei Belyi participated in Proletkul't activities in a number of areas, but the Театральное отделение (TEO) Наркомпроса was an area of particularly intense contact. It was here that the festivals of the Revolution were organized, with Ivanov a particularly influential participant (Зубарев, 1996; 1998; Берд, 2006). More importantly, however, was that it was TEO that administered institutes such as the Petrograd Институт живого слова and the Moscow Государственный институт декламации (later. Институт слова). Here representatives of each trend came together and worked out lines of research that would be influential for the next decade. The ideas of Isegoria, of Logos and of collectivism coexisted and came into many fascinating combinations. Thus at the opening of the Petrograd institute Lunacharskii defined the purpose of the institution: «надо учить говорить [публично] весь народ от мала до велика» (Записки..., 1919: 23), while Zelinskii argued that «Афинская демократия была той ячейкой, которой было вскормлено живое слово. Дальнейшая история античного мира типична также и потому, что она доказывает нам неразрывность этих двух понятий - демократии и живого слова» (Записки..., 1919: 8). In 1921 N.K. Krupskaia was proclaiming that «Россия — новая Афина» (Крупская, 1921). Speaking at the opening of the Moscow Institute Lunacharskii (Луначарский, 1981) proclaimed:

Раздел 1. История «живого слова»: люди, институты, теории

«Государственный институт декламации призван работать в области слова. Этим самым он отвечает основной нашей цели и основному тону великой русской революции - нашему устремлению к панпсихизму, широкому коллективному чувствованию».

Here once again we see the Bogdanovite elements of Lunacharskii's thought, which coexisted with the other tends.

Clearly the syncretic conception of живое слово was an unstable phenomenon, but which elements became accentuated as time went on depended more on the institutional context within which the conception was articulated and received than any purely intellectual factors. As the Revolution was isolated and the process of bureaucratic degeneration accelerated after the defeat of the German Revolution in 1923, the counter-revolutionary process ran counter to the democratic elements of «живое слово» and the collectivist elements became combined with the deadening hand of bureaucracy and officialdom. The Party line was claimed to be the distilled essence of proletarian consciousness, and the language of Party leaders as the quintessence of proletarian speech. The First Five Year Plan of course proved an important watershed, after which the primacy of «живое слово» was definitively replaced by that of «печатное слово» as literature began to acquire a special status as something akin to the «апофеоз» of the word. As Katerina Clark (2011: 82) has recently observed:

The emphasis on letters also has to do with permanence, rationalization, and consolidation. Writing is a way to give governance to speech. Behind this prejudice is the view that there is a hidden order in speech that becomes manifest in writing. And in Stalinist Russia writing emerged as the highest occupation because it was felt that it would reveal the truth of the order to be found in Bolshevik experience, the reason behind it.

Instead of state being absorbed by civil society, which was the precondition for true democracy, civil society was absorbed by the state. The whole political discourse was fa- 
tally distorted as a result, and this places significant obstacles in the way of the researcher seeking to trace the continuities and ruptures in Soviet thought. Crucial in approaching this question is the institutional setting in which the ideas developed.

The oratory section of the Petrograd Institute became Го- скурсы техники речи which provided courses «подготовка руководителей-инструкторов и преподавателей... для учреждений политпросвета профобра и соцвоса». There were three areas of specialism: «a) литература, творчество и журналистика, б) речевая педагогика, с) публичная речь» (Ц1А- ИПД. СПб. Ф. 8720. Оn. 1. Ед. хр. 4. Л. 1). The staff remained of a very high calibre, including most of the staff from the Oratory Section of the Институт живого слова, but the research base was largely transferred to Научноисследовательский институт сравнительной истории литератур и языков Запада и Востока (ИЛЯЗВ), which shared many staff. The Лаборатория публичной речи at ИЛЯЗВ, which was set up by L.P. Iakubinskii and K.A. Érberg was an important point of institutional continuity between the institutions. (See Брандист, 2007 and Brandist, 2008) However, in the 1930s, Госкурсы техники речи became Институт агитации им. В. Володарского, where agitation was finally transformed from intervention in free assemblies to management control techniques to cajole people into carrying out tasks that had been decided in advance (see Брандист, 2007). «Живое слово» continued to be studied by figures such as Boris Larin $(1928 ; 1931)$ and others in pioneering work on argot, but from the late $1920 \mathrm{~s}$, such phenomena were increasingly presented as a 'problem' to be overcome.

\section{References}

Берд Р. Вяч. Иванов и массовые празднества ранней советской эпохи. 2006. URL: http://imwerden.de/pdf/berd_vjach_ivanov_i_massovye_prazdnestva_2006_text.pdf (accessed 27 May 2012).

Богданов А.А. Не надо затемнять // Ко всем товарищам. Париж. 1910.

Богданов А.А. Философия живого опыта. Пг.; М., 1923.

Брандист К.С. Константин Сюннерберг (Эрберг) и исследование и преподавание живого слова и публичной речи в Петрограде-Ленингра- де 1918-1932 гг. //

Ежегодник Рукописного отдела Пушкинского дома на 2003-2004 годы. СПб., 2007.

Бухарин Н.И. Теория исторического материализма. М., 1922.

Записки института живого слова. 1919. Вып. 1.

Зелинский Ф.Ф. Значение ораторского искусства // Искусство и народ. Пг., 1922.

Раздел 1. История «живого слова»: люди, институты, теории

Зубарев Л.Д. Вячеслав Иванов в театральном отделе Наркомпроса // Русская филология. 1997. Вып. 8.

Зубарев Л.Д. Вячеслав Иванов и театральная реформа первых

послереволюционных лет // Начало 4. 1998.

Иванов В.И. Предчувствия и предвестия. Новая органическая эпоха и театр

будущего // Собрание сочинений. Брюссель, 1974/1906. Т. 2.

Иванова И. Развитие понятия «живого слова» в русской культуре конца XIXначала века (от словосочетания к официальному институту) // Contributions suisses au ХШe congrès mondial des slavistes à Lublijana, août 2003. Bern, 2003.

Кремер А., Мартов Ю. Об агитации. Женева, 1896. 
Крупская Н.К. Главполитпросвет и искусство // Правда. 1921. 13 фев.

Ларин Б.А. О лингвистическом изучении города // История русского языка и общее языкознание (Избранные работы). М., 1977.

Ларин Б.А. Западноевропейские элементы русского воровского арго // Язык и литература. Л., 1931. Т. VII.

Левченко М. Индустриальная свирель: Поэзия пролеткульта. СПб.,2007.

Ленин В.И. «Что делать?» Наболевшие вопросы нашего движения. 1902. URL: http://www.trud-ros.ru/teor/lenin_chto_del.htm (accessed 27 May 2012).

Ленин В.И. О старых, но вечно новых истинах // Полное собрание сочинений. М., 1973. Т. 20.

Луначарский А.В. На открытии Государственного института декламации // О массовых празднествах, эстраде, цирке. М., 1981.

НуарэЛ. Орудие труда. Киев, 1926.

Плеханов Г.И. О задачах социалистов в борьбе с голодом в России (письма к молодым товарищам) // Собрание сочинений. М., 1923. Т. 3.

Biggart J. Bukharins Theory of Cultural Revolution // The Ideas of Nikolai Bukharin. Oxford, 1992.

Brandist C. Sociological Linguistics in Leningrad: The Institute for The Comparative History of the Literatures and Languages of the West and East (ILJaZV) 1921-1933 // Russian Literature. LXIII, II, III, IV. 2008.

Cartledge P. Comparatively Equal. // Dëmokratia: A Conversation on Democracies Ancient and Modern. Princeton, 1996.

Clark K. Moscow, the Fourth Rome: Stalinism, Cosmopolitanism, and the Evolution of Soviet Culture, 1931-1941. Cambridge Mass, 2011.

Cliff T. Lenin: Budding the Party. London, 1975.

Eagleton T. The Ideology of the Aesthetic. Oxford, 1990.

Ginzburg C. History, Rhetoric and Proof. Hanover and London, 1999.

Noiré L. Logos: Ursprung und Wesen der Begriffe. Leipzig, 1885.

Vickers B. In Defence of Rhetoric. Oxford, 1988.

Wood E.M. Demos vs. "We the People": Freedom and Democracy Ancient and Modern 11 Dëmokratia: A Conversation on Democracies Ancient and Modern. Princeton, 1996.

\section{AРХИВ}

Центральный государственный архив историко-политических документов Санкт-Петербурга. Ф. 8720, Институт агитации им. В. Володарского. 